\title{
SELF-REGULATED LEARNING AND DIGITAL LEARNING ENVIRONMENT: ITS' EFFECT ON ACADEMIC ACHIEVEMENT DURING THE PANDEMIC
}

\author{
Nani Sutarni*, M. Arief Ramdhany, Achmad Hufad, Eri Kurniawan \\ Universitas Pendidikan Indonesia, Indonesia \\ *e-mail: nanisutarni@upi.edu
}

\begin{abstract}
The unprecedented changes in the education sector due to the recent pandemic demand teachers and students to adapt to new ways of learning via online platforms. A plethora of latest research has investigated various topics such as online learning platforms, online learning materials, and teacher/student perceptions; however, little is known about the link between online learning and achievement. Occupying this lacuna, this study specifically sought to examine the relationship between self-regulated learning (SRL), the digital learning environment, and student' academic achievement during the pandemic. The population of this research was 1,800 students (freshmen, sophomore, junior, and senior class) enrolled for the Introduction to Management course at a state university in Bandung, Indonesia. Selected using a proportionate random sampling, 317 students participated as the respondents. The data were collected through questionnaire surveys, while the Structural Equation Model (SEM) was employed to analyze the interrelationship among the construct variables. The results of this study show that promoting SRL may affect the optimization of the digital learning environment and academic achievements. Students with better self-regulated learning ability can somehow optimize their digital learning environment and be more progressive in terms of academic achievement.
\end{abstract}

Keywords: academic achievement, digital learning environment, pandemic, self-regulated learning.

\section{SELF-REGULATED LEARNING DAN LINGKUNGAN PEMBELAJARAN DIGITAL: PENGARUHNYA TERHADAP PRESTASI AKADEMIK PADA MASA PANDEMI}

\begin{abstract}
Abstrak: Perubahan di sektor pendidikan akibat pandemi baru-baru ini menuntut guru dan siswa untuk beradaptasi dengan cara-cara baru dalam proses pembelajaran. Saat ini telah terdapat banyak penelitian yang berfokus pada platform, materi dan persepsi guru dan murid tentang pembelajaran daring, namun hanya sedikit yang fokus pada hubungan antara pembelajaran tersebut dan hasil belajar siswa. Tujuan penelitian ini adalah mengkaji keterkaitan antara self-regulated learning, lingkungan belajar digital, dan prestasi akademik siswa selama masa pandemi. Populasi dalam penelitian ini adalah 1.800 mahasiswa (mahasiswa baru, mahasiswa tingkat dua, tingkat tiga, dan tingkat akhir) di salah satu perguruan tinggi negeri di Kota Bandung, yang telah mengikuti mata kuliah Pengantar Manajemen. Dengan menggunakan proportional random sampling, 317 siswa berpartisipasi sebagai responden. Teknik pengumpulan dilakukan melalui survei dengan menggunakan kuesioner, sedangkan teknik analisis data menggunakan Structural Equation Model (SEM) untuk mengkaji hubungan antar variabel konstruk. Hasil penelitian mengungkapkan bahwa penerapan self-regulated learning dapat mempengaruhi optimalisasi lingkungan pembelajaran digital dan prestasi akademik. Siswa dengan self-regulated learning yang lebih tinggi dapat mengoptimalkan lingkungan pembelajaran digital dan lebih progresif dalam prestasi akademik.
\end{abstract}

Kata Kunci: lingkungan pembelajaran digital, pandemik, prestasi akademik, self-regulated learning.

\section{INTRODUCTION}

The spread of the novel coronavirus disease 2019 (COVID-19) pandemic since the beginning of 2020 has globally changed various aspects of human life, including social life, health, economy, and education (Sahu, 2020). This outbreak has undoubtedly impacted the educational pedagogies in Indonesia. Among the immediate changes is the prohibition of face-toface learning to curb coronavirus transmission among students and teachers. Students who initially studied in class now have to learn from home; teachers also have to teach from home. One of the effectual ways to circumvent this condition 
is through online learning supported by digital learning facilities as an evolution of distance learning (Courtney \& Wilhoite-Mathews, 2015). The teachers have to prepare the course materials and pedagogical approaches, such as Massive Open Online Courses (MOOCs), that students can access online synchronously and asynchronously (Kaplan \& Haenlein, 2016).

Proper use of digital learning devices in online learning may affect students' academic achievement (Salvo, Welch, \& Shelton, 2019). Self-regulated learning (henceforth SRL) has been proposed as an alternative strategy to facilitate students' digital learning environment and academic achievement. SRL refers to the ability of students to understand and control their learning and to make adjustments in learning processes in response to their perception of feedback regarding the status of learning (Harris, Graham, MacArthur, Reid, \& Mason, 2011; Schunk \& Zimmerman, 1998).

Students with higher level of SRL can optimize the digital learning environment and be more progressive in academic achievement (Barnard-Brak, Paton, \& Lan, 2010; Wang, Shannon, \& Ross, 2013; Zimmerman \& Schunk, 2012). SRL has a vital role to play in education, especially in leveraging student learning achievement. SRL impacts significantly on student achievement in secondary and higher education (Fredricks, Blumenfeld \& Paris, 2004). SRL affects academic emotions, which in turn impact on increasing academic achievement (Pekrun, Goetz, Titz, \& Perry, 2002).

Theoretically, SRL is a process model using a cyclical structure in the phases of before (forethought), during (performance), and after (self-reflection) learning that students believe they have the ability to achieve the desired outcome in the specific learning environment (Panadero, 2017; Peel, 2020; Zimmerman, 2011). It is the ability to grasp one's learning environment and how to control it (Schraw, Crippen, \& Hartley, 2006). Self-regulation is formally defined as ideas, feelings, and actions self-generated and strategically designed and tailored to achieve personal goals (Zimmerman, 1989). Self-regulated abilities encompass goalsetting, self-monitoring, self-instruction, and self-reinforcement (Harris et al., 2011; Schraw et al., 2006; Schunk, 1995). The ability to self- regulate or to attain academic success should not be confused. Self-regulation; however, is an independent process and behavior, by which learners turn intellectual abilities into skills or competencies (Zimmerman, Bonner, \& Kovach, 1996) and habits through a process of development (Butler, 2002) that emerges from guided practice and feedback (Paris \& Paris, 2001).

Effective and efficient students control themselves, evaluate activities, set realistic goals, and choose, adapt, or devise approaches to achieve their goals. They also track progress in the workplace, control distracting feelings, and decline motivation, and change success-friendly strategies. These students ask questions, make notes, and dedicate their time and energy to their learning (Paris \& Paris, 2001).

SRL is both a process and an outcome. As a process, SRL can be seen as learners take autonomous actions in preparing, implementing, and assessing their learning. This can be seen as an outcome of learners' propensity to direct their learning (Brockett \& Hiemstra, 2018). The process and outcome aspects of SRL are also critical. As one creates a picture of one's learning objectives and associated challenges, one will slowly become more likely to set targets for one's further development.

The fundamentals of SRL are the rationale for learning, responsibility for learning, capability for-from learning, and social environment for learning (Peel, 2020). The rationale for learning concerns the learning purposes and goals. Responsibility for learning consists of applying an appropriate strategy to activate knowledge and monitor learning progress. Capability forfrom learning deals with product and process and acknowledgment of learning outcomes. Finally, the social environment for learning is about the interaction of students to internalize a desire and commitment for learning.

To support teaching and learning in the pandemic time, teachers and students can utilize the educational technology in terms of the digital learning environment. Teachers and students can take advantage of the digital learning environment in an integrated system, which can be divided into four pedagogical areas: content, course management, interaction, and assessment (Goudzwaard, Finkelstein, \& 
Petersen, 2017). In a certain course, the teacher may create, share, and select course materials for students. In the course management, the teacher may collect, organize, and share the content on a digital platform, while tracking students' progress and organize the group work. The interaction area mainly enhances students' engagement and collaboration and reflects the lesson in synchronous and asynchronous ways. The assessment is performed using specific measurement tools and shared feedbacks.

Students' academic achievement, in general, can be measured by intellectual behaviors, interpersonal behaviors, and intrapersonal behaviors (Oswald, Schmitt, Kim, Ramsay, \& Gillespie, 2004). Whereas intellectual behaviors may be reflected by knowledge, learning, and curiosity, interpersonal behaviors may be seen in leadership, interpersonal skills, and learning involvement. Meanwhile, intrapersonal behaviors may be manifested in the ability to handle stress, adaptability, and perseverance.

Several previous studies have underscored the relationships between the digital learning environment and academic achievement before the pandemic time (Ceylan \& Kesici, 2017; Jena, 2013; Peters, 2000). The relationship between SRL and academic achievement has also been discussed by many researchers (Dent \& Koenka, 2016; Kosnin, 2007; Wolters \& Hussain, 2015; Zimmerman, 1990), correspondingly before the pandemic times. In a similar vein, studies about the relationship between SRL and the digital learning environment abound (Johnson \& Davies, 2014; Yamada, Yin, Shimada, Kojima, Okubo, \& Ogata, 2015; Yot-Domínguez \& Marcelo, 2017), yet all these were conducted prior to this corona pandemic.

In the pandemic time, numerous studies have also explored the relationship of SRL, digital learning environment, and academic achievement in several different aspects. Putri, Muqodas, Sasqia, Abdulloh, \& Yuliyanto (2020), for instance, scrutinized SRL of elementary school students through the concrete-pictorialabstract approach during the Covid-19 pandemic. Kusumaningrum, Budiarti, Triwiyanto, \& Utari (2020) also examined the effect of distance learning in an online learning framework on the learning independence of students in elementary school students in the coastal and mountainous areas during the Covid-19 pandemic. Similarly, Hudaifah (2020) found that SRL affects students' problem-solving, learning outcomes, and mathematical connection abilities. Additionally, she claimed that SRL is related to academic procrastination in accelerated learners and its relation to learning achievement.

The role of SRL in pandemic times has likewise been widely reported by other researchers abroad. Focusing on the $8^{\text {th }}$ grade students from four middle schools, Cai, Wang, $\mathrm{Xu}$, \& Zhou (2020) demonstrated that SRL of some subjects was evidently compelling under a particular pandemic period. Other researchers, Uka \& Uka (2020), revealed that the student's experience with the transition from primary to secondary school might affect SRL and motivation. Involving physics students from five universities in Germany, Austria, and Croatia during the COVID-19 pandemic, Klein, Ivanjek, Dahlkemper, Jeličić, Geyer, Küchemann, \& Susac (2021) discovered that a digital learning environment promoted academic achievement. What is missing from the previous studies is an inquiry that looks at the connection between SRL and student achievement.

Therefore, this study aimed to examine the relationship between SRL, digital learning environment, and the academic achievement of university students the during the pandemic time. This study sought to scrutinize how SRL can enhance the digital learning environment and academic achievement in the pandemic context.

\section{METHOD}

Using a quantitative approach, this study attempted to describe the variables and verify their interrelation of variables (Churchill \& Iacobucci, 2005). The subjects of this study were the students (freshmen, sophomore, junior, and senior class) at the Faculty of Economic and Business Education at a state university in Bandung, who were enrolled for the Introduction to Management course. The population was 1,800 students from seven study programs at the Faculty. Using proportional random sampling, the obtained sample was 317 , as presented in Table 1. 
Table 1. Population and Sample of Students

\begin{tabular}{lcc}
\hline Study Programs & Population Sample \\
\hline Accounting Education & 266 & 47 \\
Business Education & 254 & 45 \\
Office Management Education & 270 & 47 \\
Economic Education & 258 & 45 \\
Accounting & 256 & 45 \\
Management & 262 & 46 \\
Islamic Economics and Finance & 234 & 42 \\
\hline Total & 1800 & 317 \\
\hline
\end{tabular}

The instrument of this study was a questionnaire administered to 317 students as respondents. The data were collected through surveys (5 rating scale) distributed via Google form to the respondents. The instrument was based on the operationalization of these constructs as follows; a ) Self-regulated Learning (SRL) as an exogenous latent construct consists of four observed variables: Rationale for Learning (SRL-1) measured by four indicators, Responsibility for Learning (SRL-2) measured by four indicators, Learning Capability (SRL-3) measured by four indicators, and Social Environment (SRL-4), measured by three indicators so that there are 15 items to measure this construct; b) Digital Learning Environment (DLE) as a exogenous as well as endogenous latent construct consists of four observed variables: Content (DLE-1), Course Management (DLE-2), Interaction (DLE-3), and Assessment (DLE-4) that each of them measured by three indicators so that there are 12 items to measure this construct; and c) Academic Achievement (AAC) as an endogenous latent construct consists of three observed variables: Intellectual Behaviors (AAC-1), Interpersonal Behaviors (AAC-2), and Intrapersonal Behaviors (AAC-3) that each of them measured by three indicators so that there are 9 (nine) items to measure this construct.

Before distributing the questionnaire, the validity and reliability of the instrument were tested to other students $(n=30)$. The results of the tests revealed that all items were valid and all constructs were reliable. All of 15 items of Self-regulated Learning (SRL) were valid, 12 items of Digital Learning Environment (DLE) were valid, and 9 (nine) items of Academic Achievement (AAC) were valid. The reliability test showed that all constructs were reliable (above .7).

The data were tested and evaluated by multivariate causal relationships with structural equation modeling (SEM) technique, as a combination of two statistical methods: confirmatory factor analysis and path analysis (Fan, Chen, Shirkey, John, Wu, Park, \& Shao, 2016). The average score (mean) and the standard deviation for each indicator, observed variable, and latent construct (with the minimum ideal score is 1.0 and the maximum ideal score is 5.0) were calculated, then the actual average scores were categorized into five categories (Cooper \& Schindler, 2006).

In performing SEM, the model specification of the hypothesized relationships among the variables in SEM based on relevant theories was first defined. The model in question is specified in Figure 1, showing three main hypotheses.

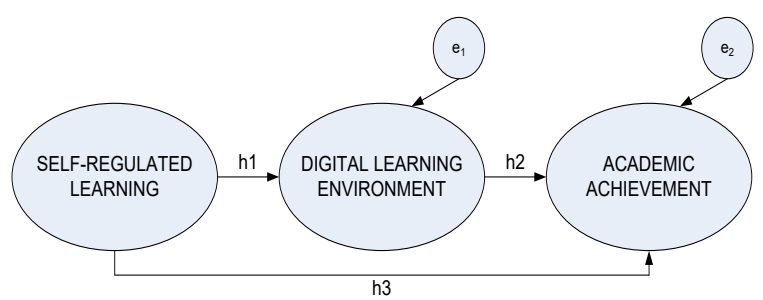

Figure 1. Model Specification of SRL and Digital Learning Environment on Academic Achievement

Then, model identification was made to ascertain whether the model was over-identified, just-identified, or under-identified so that the measurement and structural model could be estimated. The next step was to evaluate whether the model performance fits several quantitative indices for the overall goodness of fits (GoF), such as $\chi^{2}$, RMSEA, CFI, GFI, NFI, and other indices. The last step was the modification of the model to improve its suitability, if needed. The Analysis of Moments Structures (AMOS) software from IBM SPSS was employed to support the SEM calculation.

\section{FINDINGS AND DISCUSSION Findings}

The study results based on the reference to the mean value, standard deviation, and category are presented in Table 2. 
Table 2. Mean Self-Regulated Learning, Digital Learning Environment, and Academic Achievement

\begin{tabular}{|c|c|c|c|c|}
\hline Construct & Manifest Variables & Mean & $S D$ & Category \\
\hline & Rationale for Learning (SRL-1) & 4.031 & .794 & High \\
\hline & Responsibility for Learning (SRL-2) & 3.809 & .822 & High \\
\hline & Learning Capability (SRL-3) & 4.392 & .802 & Very High \\
\hline & Social Environment (SRL-4) & 3.974 & .818 & High \\
\hline \multicolumn{2}{|c|}{ Self-regulated Learning (SRL) } & 4.052 & .809 & High \\
\hline & Content (DLE-1) & 4.053 & .824 & High \\
\hline & Course Management (DLE-2) & 4.284 & .821 & Very High \\
\hline & Interaction (DLE-3) & 4.107 & .832 & High \\
\hline & Assessment (DLE-4) & 3.974 & .851 & High \\
\hline \multicolumn{2}{|c|}{ Digital Learning Environment (DLE) } & 4.105 & .832 & High \\
\hline & Intellectual Behaviors (AAC-1) & 4.117 & .769 & High \\
\hline & Interpersonal Behaviors (AAC-2) & 4.152 & .790 & High \\
\hline & Intrapersonal Behaviors (AAC-3) & 3.981 & .836 & High \\
\hline \multicolumn{2}{|c|}{ Academic Achievement (AAC) } & 4.083 & .798 & High \\
\hline
\end{tabular}

Based on Table 2, Self-regulated Learning, Digital Learning Environment, and Academic Achievement can be categorized as high. To deepen the analysis, the interrelation of Self-Regulated Learning, Digital Learning
Environment, and Academic Achievement can be evaluate using SEM. To evaluate the interrelationship among the variables, the calculation of the overall model using SEM was estimated (see Figure 2 and Table 3).

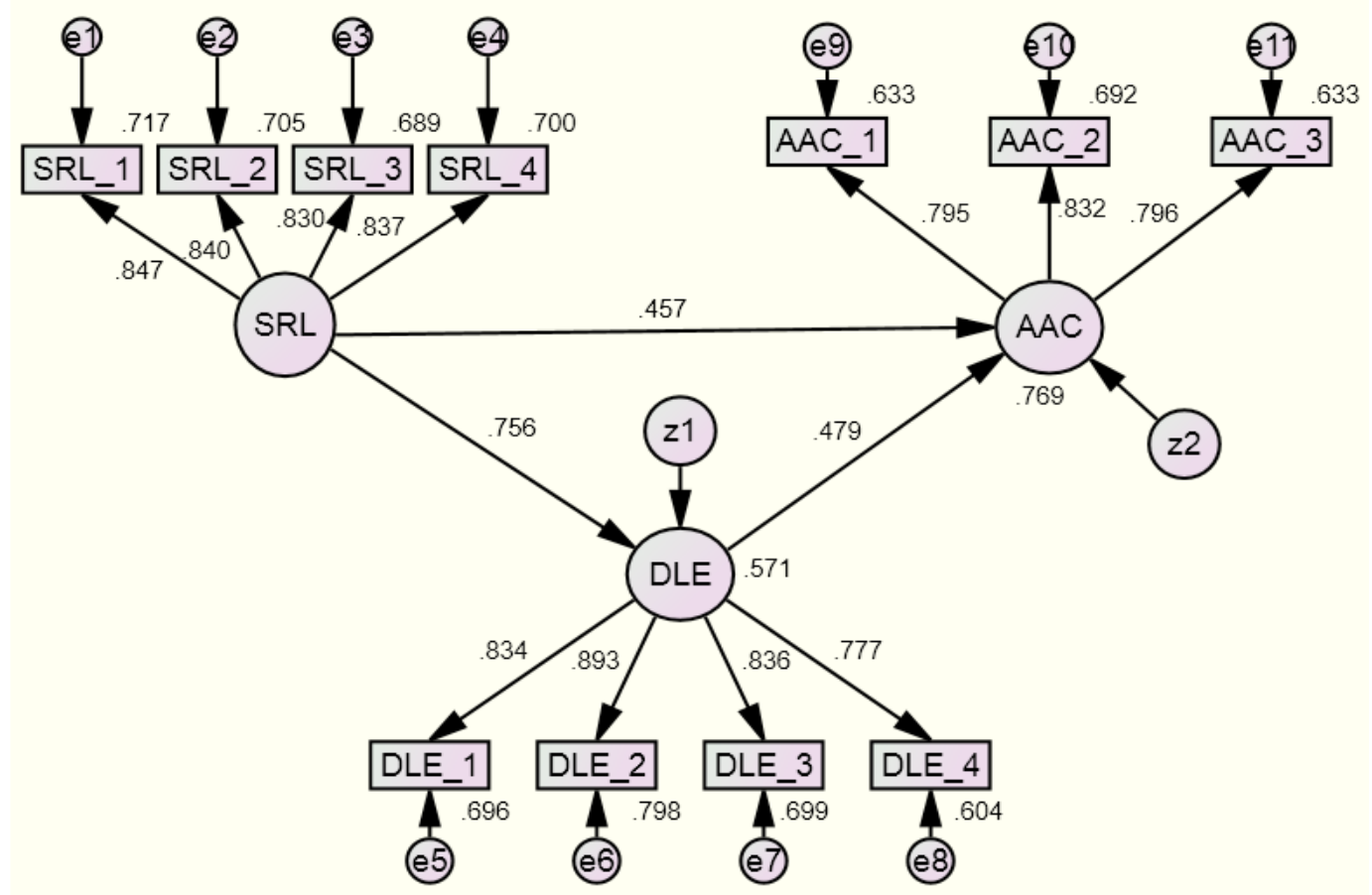

Figure 2. Overall Model of Interrelation of Self-Regulated Learning, Digital Learning Environment, and Academic Achievement 
Table 3. Model Estimation of Interrelation of Self-Regulated Learning, Digital Learning Environment, and Academic Achievement

\begin{tabular}{|c|c|c|c|c|c|c|c|c|}
\hline & & Estimate & Beta & S.E. & C.R. & $P$ & Sig. & $R$-Squared \\
\hline$\overline{\text { DLE }}$ & $\leftarrow$ SRL & .745 & .756 & .057 & 12.954 & .000 & Sig. & .571 \\
\hline $\mathrm{AAC}$ & $\leftarrow \mathrm{SRL}$ & .429 & .457 & .068 & 6.343 & .000 & Sig. & .769 \\
\hline $\mathrm{AAC}$ & $\leftarrow$ DLE & .457 & .479 & .069 & 6.616 & .000 & Sig. & \\
\hline SRL 1 & $\leftarrow \mathrm{SRL}$ & 1.000 & .847 & & & & & \\
\hline $\mathrm{SRL}^{-} 2$ & $\leftarrow \mathrm{SRL}$ & .992 & .840 & .054 & 18.296 & .000 & & \\
\hline $\mathrm{SRL}^{-} 3$ & $\leftarrow \mathrm{SRL}$ & .980 & .830 & .055 & 17.965 & .000 & & \\
\hline $\mathrm{SRL}^{-} 4$ & $\leftarrow \mathrm{SRL}$ & .989 & .837 & .054 & 18.206 & .000 & & \\
\hline DLE-1 & $\leftarrow$ DLE & 1.000 & .834 & & & & & \\
\hline $\mathrm{DLE}^{-} 2$ & $\leftarrow$ DLE & 1.070 & .893 & .054 & 19.752 & .000 & & \\
\hline DLE $^{-} 3$ & $\leftarrow$ DLE & 1.002 & .836 & .056 & 17.890 & .000 & & \\
\hline $\mathrm{DLE}^{-} 4$ & $\leftarrow$ DLE & .931 & .777 & .058 & 16.046 & .000 & & \\
\hline $\mathrm{AAC}_{-} 1$ & $\leftarrow \overline{A A C}$ & 1.000 & .795 & & & & & \\
\hline $\mathrm{AAC}^{-} 2$ & $\leftarrow$ AAC & 1.046 & .832 & .066 & 15.852 & .000 & & \\
\hline $\mathrm{AAC}^{-} 3$ & $3 \leftarrow \mathrm{AAC}$ & 1.000 & .796 & .066 & 15.045 & .000 & & \\
\hline
\end{tabular}

The model estimation of the overall model indicates that all loading factors of the measurement model are above .7 in which the values can reflect each construct. In the structural model, it was found that SRL had a positive direct effect on the digital learning environment and positively affected student academic achievement. The indirect effect of SRL on academic achievement through the digital learning environment was also significant. It means that the digital learning environment can function as a variable that connect SRL to improve academic achievement. Similarly, the digital learning environment evinced a positive direct effect on academic achievement. The $R$-Squared values indicate a better fit for the model. In short, the high SRL may enhance academic achievement supported by the digital learning environment. The students' capacity to self-regulate will determine the usefulness of digital learning in online class during the pandemic time that directly and indirectly enhance academic achievement.

To confirm the goodness of fit of the model, all indices met the target. The estimates led to the model goodness-of-fit (see Table 4). In general, the goodness-of-fit of the model indicates that the model could reproduce the data and that the model was consistent with the data; it does not necessarily require adjustment or modification to improve the model fit.

Table 4. SEM Goodness of Fit (GoF)

\begin{tabular}{|c|c|c|c|}
\hline GoF Indices & Target & Estimates & Fitness \\
\hline Chi-Square & Small value & $\chi^{2}=206.72$ & good fit \\
\hline & $\begin{array}{l}p=0 \text { (saturated }) \\
\text { or } p>.05\end{array}$ & $\tilde{p}=.000$ & \\
\hline $\mathrm{NCP}$ & Small value & 165.73 & good fit \\
\hline & Narrow interval & $(124.54 ; 214.44)$ & \\
\hline RMSEA & $\begin{array}{l}.098 \leq \mathrm{RMSEA} \leq .129 \\
p<.05\end{array}$ & .113 & good fit \\
\hline ECVI & Small value and close to saturated ECVI & $\begin{array}{l}\mathrm{D}^{*}=.812 \\
\mathrm{~S}^{*}=.628 \\
\mathrm{I}^{*}=.819\end{array}$ & good fit \\
\hline AIC & Small value and close to saturated AIC & $\begin{array}{l}\mathrm{D}^{*}=256.73 \\
\mathrm{~S}^{*}=132.00 \\
\mathrm{I}^{*}=2722.88\end{array}$ & good fit \\
\hline CAIC & Small value and close to saturated CAIC & $\begin{array}{l}\mathrm{D}^{*}=375.70 \\
\mathrm{~S}^{*}=446.09 \\
\mathrm{I}^{*}=2775.23\end{array}$ & good fit \\
\hline NFI & $\mathrm{NFI} \geq .90$ & .923 & good fit \\
\hline CFI & $\mathrm{CFI} \geq .90$ & .937 & good fit \\
\hline IFI & IFI $\geq .90$ & .938 & good fit \\
\hline RFI & $\mathrm{RFI} \geq .90$ & .908 & good fit \\
\hline RMR & $\mathrm{RMR} \leq .08$ & .037 & good fit \\
\hline GFI & GFI $\geq .90$ & .909 & good fit \\
\hline AGFI & $\mathrm{AGFI} \geq .90$ & .853 & close fit \\
\hline
\end{tabular}

Notes: $D=$ Default Model; $S=$ Saturated; $I=$ Independence 


\section{Discussion}

In the SRL construct, students perceived Learning Capability (SRL-3) as the highest. Here, the students believed that the overall learning process in the Introduction to Management subject suited their expectations and that most of them could follow the learning process. They felt that they were capable of attending the course. Most students believed that they would be successful in learning the material. Ease of access to many learning resources (such as textbooks, the internet, and other learning resources) was assumed to facilitate success in learning. Most students were pleased to learn new things about the material, especially if the lecturer presented interesting, current issues. The final grade they received also matched their efforts and expectations.

Furthermore, the students perceived the Rational for Learning (SRL-1) as also high. In this context, the students began lessons at the beginning of the semester by relating to the acquisition of certain skills. Some students already had prior knowledge related to this subject to strengthen the achievement of their goals in learning. The students were interested in this course material because this course is a primary subject fundamental to studying advanced materials. With the proper direction from the lecturer regarding the learning objectives in this course, the students became more confident in achieving these learning goals. From the beginning of the lecture, the lecturers had emphasized that students had to have more autonomous and distance learning abilities. Students' motivation to study independently could be further enhanced at this phase.

In the Social Environment (SRL-4), the students collaborated with other students to complete several individual and group assignments, and performed project-based learning with other students online using a digital platform. Due to the pandemic, most first-year students of 2021 had even never experienced face-to-face lectures. They had never met their lecturers and friends in person; many of them had never physically come to campus.

The students had high perceptions of Responsibility for Learning (SRL-2) even though their achievement in this construct was the lowest. They understood the expectations of this course and strove to stick with the learning activity procedures. They felt that the lecturer was competent enough to deliver the subject matter so that students had no difficulty grasping the course as expected. Their efforts in SRL have been in line with online self-learning strategies with synchronous and asynchronous approaches. To scaffold the content, the students may ask the assistance provided by lecturers. The students themselves, together with the lecturers, monitored their learning progress.

With confidence in their abilities in this self-regulated learning, students can more easily adapt to the digital learning environment. To support the Content (DLE-1), the lecturers first have to create the content based on lesson planning in a platform that is easily accessible to students. Lecturers can share this material through various channels.

The students perceived that Course Management(DLE-2) was adequate to experience "traditional classes" online via zoom meetings or Google meet. The institution has provided the students with the Sistem Pembelajaran Online Terpadu (SPOT) or the Integrated Online Learning System to facilitate the digital learning environment. With an integrated system, lecturers can track student progress and record or retrieve student attendance. The students with high SRL tended to continue to follow lessons from start to finish.

Interaction(DLE-3) describes the existence of online facilitated learning interactions through the prepared digital channels. The assessment (DLE-4) includes the digital submission of assignments through a specific channel that students can quickly submit. The lecturers then may grade the written tasks. Measurement and evaluation can also be done using assessment tools such as Google forms.

The Intellectual Behaviors (AAC-1) domain of the students' academic achievement was perceived as high, reflecting the capacity of students' knowledge of the learning materials. The students described the learning process in a semester as satisfactory to enrich their learning experiences. Overall, the level of student curiosity about the subject tended to increase after attending the lecture.

The domain of Interpersonal Behaviors (AAC-2) of the students' academic achievement was also perceived as high, reflecting leadership, interpersonal skills, and learning involvement. 
The students at least were motivated to lead themselves to engage in an online learning process. Although using online learning, the students were able to interact with others effectively by proper communication and listening to each other via the digital platform, and practicing and showing a good attitude and deportment. In learning involvement, the students were able to sustain participation and concentration during and after the learning process. They desired to find out and solve the problems proposed in the learning materials. They were able to revisit and reflect on the learning process.

Perceived as high, the Intrapersonal Behaviors (AAC-3) domain reflected the student's ability to handle the stress, adaptability, and perseverance. Most students seemed to have the ability to control the anxiety regarding the difficulty of learning, time management, and access to learning resources. The current students between the ages of 16 and 24 belong to generation $\mathrm{Z}$ or post-millennials who have a more global insight. This generation $\mathrm{Z}$ has high adaptability to new digital technologies (Bejtkovskỳ, 2016). Consequently, they are accustomed to using the latest technology compared to generation X or Y. Most of them believe the phrase "if you want something to go well, you have to do it yourself independently," which refers to self-directed, self-sufficient, and self-regulated learning. They also have certain perseverance that makes them more realistic by experiencing various world-changing events, including the COVID-19 pandemic and family financial challenges. However, they can still collaborate competitively as a 'coopetition' (a portmanteau of cooperation and competition) (Luo, 2007).

The findings of this study about the interrelationship among SRL and academic achievement through a digital learning environment reaffirm the notion that SRL as an instruction architecture is more readily available and applied in the digital learning environment (Johnson \& Davies, 2014). It was found that rationale for learning is fundamental of SRL in which the lecturers prepare the instructional design with detailed directions and specific instruction and share with the students in interactive course management. This preparation focuses on ensuring that students understand the learning objective using selective learning strategies to monitor their progress (Winne, 2005). Before the pandemic, the students rarely utilized an online course management system where they could access digital course materials, assignments, discussions, assessments, and other learning activities (Vovides, Sanchez-Alonso, Mitropoulou, \& Nickmans, 2007).

Nevertheless, during the pandemic, the students are compelled to access the course management online. Online course management has several advantages for students that support student-centered activities in asynchronous learning. The system interactivity enables personalized and flexible instruction and intermediate feedback (Zhang, Zhao, Zhou, \& Nunamaker Jr, 2004). This suggests that SRL can develop well in a digital learning environment.

SRL is linked to various student characteristics, such as self-efficacy, motivation, and emotional intelligence (Efklides, 2011). After receiving guidance from the lecturers, the students could access materials and learning resources, then determined their progress toward goals in a specific time. Self-efficacy and motivation of the students can directly enhance the students' interpersonal behavior. The finding confirms that students' perception of the social environment in SRL can increase student interpersonal behavior (Wei, Peng, \& Chu, 2015).

By way of SRL, the students honed the rationale for learning at least by understanding the goal setting and task analysis and maintaining the level of learning motivation. This finding confirms the notion that goal setting and time management are positively correlated with students' academic achievement (Handoko, Gronseth, McNeil, Bonk, \& Robin, 2019), and that goal setting and task interest are the main predictors of academic completion (Reparaz, Aznárez-Sanado, \& Mendoza, 2020). Moreover, the SRL strategies can predict learner behavior and goal attainment in online courses (Kizilcec, Pérez-Sanagustín, \& Maldonado, 2017).

By responsibility for learning, the students can adjust their learning strategy to follow the online learning process and can control and monitor their learning progress at a specific time (Song \& Hill, 2007). The students can gradually strengthen their learning capabilities to be more independent from the start of the course to the 
end of the semester (Kondo, Ishikawa, Smith, Sakamoto, Shimomura, \& Wada, 2012). They may get actively involved in a certain socialtechnological environment to collaborate with other students, share responsibilities in a group project, and communicate with lecturers in several communication channels to enhance interaction for learning (Hamid, Waycott, Kurnia, \& Chang, 2015).

The present study's findings corroborate Bernacki, Aguilar, \& Byrnes (2011) and YotDomínguez \& Marcelo (2017) that digital learning environments offer an open entrance to new learning alternatives and preferences that bolster the gradual acquisition of self-regulation skills in online learning. Our results also coincide with Cazan (2014) that SRL is positively related to the achievement of the online courses with high self-efficacy as the main factor of SRL that predict the final grades. The finding of this study verifies that SRL can strengthen self-efficacy in studying material provided by lecturers (Brown, Peterson, \& Yao, 2016). In this case, students believe that they can follow the learning and achieve the specified learning goals. Students can also better manage their learning pace overtime to follow other online courses in the same semester (Wei, Zhou, Barber, \& den Brok, 2015). Corresponding to the research of Atmojo, Muhtarom, \& Lukitoaji (2020), the level of SRLwill determine the students to be more independent, less dependent on others in mastering the learning materials.

Most students perceived that the content of the course could make it easier for them to learn. In this regard, the class lecturers must have the readiness and competency to create, share, and curate the course materials (Martin, Budhrani, \& Wang, 2019) in an integrated online learning system. The students sometimes were baffled when accessing online material owing to the large number of materials to be downloaded and studied. In this case, Aduba \& Mayowa-Adebara (2020) suggest that the students sometimes experience confusion when accessing online material because of the large number of materials to download and study. The availability of a large number of learning materials is confusing the students. To facilitate this issue, the lectures must consider concise and comprehensive materials for students to learn independently.
Within maintainable course management, the lecturers and the students can plan, schedule, and organize the classes. Previously, the institution has set an online lecture schedule for all courses in one semester. The lecturers and the students then execute synchronous learning according to a predetermined schedule. In this course management, the lecturers and the students must acknowledge the usability advantages and disadvantages inherent in the integrated online learning system (Kakasevski, Mihajlov, Arsenovski, \& Chungurski, 2008). The lecturers may track the students' progress through the attendance lists and evaluate the progress through the digital grade book provided by the institution. In this system, the lecturers can also organize group work for project-based learning.

The use of a digital learning environment for educational purposes and the participation of effective training practices such as active, collaborative learning and student-lecturer interactions seem to be strongly positive. The findings of Laird \& Kuh (2005) suggest that specific areas of involvement in learning technology can be seen as forms of engagement in themselves. Furthermore, students using information technology can increase their opportunities for other types of involvement. It is possible for lecturers and students to interact more in a digital platform by blending online asynchronous and synchronous learning (Yamagata-Lynch, 2014). Fortunately, this online learning system can be accessed and optimized by a limited handheld device. In line with these findings, this optimization of handheld devices has also been used for patients in Health Care (Rubulotta et al., 2020).

In general, SRL can build dispositions for learning such as curiosity, cooperation, confidence, creativity, commitment, enthusiasm, persistence, imagination, and reflexivity. It can apply a range of skills and processes such as problem-solving, inquiry, experimentation, hypothesizing, researching, and investigating. As suggested by Zimmerman (2011), the outcome of academic achievement has a loopback to SRL as a basis for the next learning experience. Using the digital learning environment is no longer a novel feature for Generation $\mathrm{Z}$ students who have high adaptability to new technologies (Bejtkovskỳ, 2016). 
The proposed model lends support to several previous studies that SRL can improve the usability of the digital learning environment (Anthonysamy \& Choo, 2021; Goudzwaard et al., 2017; Johnson \& Davies, 2014; Kaplan \& Haenlein, 2016; Nietfeld, 2017; Rubulotta et al., 2020; Salvo et al., 2019; Yot-Domínguez $\&$ Marcelo, 2017). SRL can also enhance the academic achievement of students directly and indirectly through digital learning environment (Brown et al., 2016; Cazan, 2014; Ceylan \& Kesici, 2017; Dent \& Koenka, 2016; Kosnin, 2007; Wei et al., 2015; Wolters \& Hussain, 2015). Nevertheless, several issues that must be handled in SRL are monitoring the learning capability of each student, for they have different learning profiles. In addition, the lecturers must be careful with the aspect of online assessment when students have difficulties submitting the task online. Finally, the lecturers cannot directly observe learning activities that can affect students' evaluation of their intellectual behaviors. In this regard, the lecturers must have a more objective measurement to assess students' achievement.

The implication of this study is that the academic achievement of students in the time of pandemic (Covid-19) can be maintained by promoting SRL to strengthen their independency to learn at a specific pace. The students may collaborate or even compete with other students through the digital learning environment. Thus, the optimization of the digital learning environment can support the role of SRL to bolster academic achievement in normal or in pandemic times.

\section{CONCLUSION}

SRL exhibited a positive direct effect on the digital learning environment, and on students' academic achievement, directly and indirectly. The digital learning environment has also direct effect on academic achievement. In the context of the present research, the students seemed to improve their learning strategies using SRL. This is especially true of learning during the pandemic that requires students to be more autonomous. Implicationally, the lecturers have to promote SRL to maintain the learning process supported by a proper digital learning environment to reach the standard academic achievement of the students. The balance of synchronous and asynchronous learning in online classes may strengthen the level of students' engagement in SRL. In the process, the lecturers just have to make effective use of SRL so that the students can fully understand the true meaning of optimizing the use of a digital learning environment to proceed with the learning process. Howsoever, the acquired academic achievement has a loopback to SRL as a basis for the next learning experience.

\section{REFERENCES}

Aduba, D. E., \& Mayowa-Adebara, O. (2020). Online platforms used for teaching and learning during the COVID-19 era: The case of LIS students in Delta State University, Abraka. International Information \& Library Review, 1-36. https://doi.org/10.1080/10572317.2020.1 $\underline{869903 .}$.

Anthonysamy, L., \& Choo, A. (2021). Investigating self-regulated learning strategies for digital learning relevancy. Malaysian Journal of Learning and Instruction, 18(1), 29-64. http://repo. uum.edu.my/id/eprint/27979.

Atmojo, S. E., Muhtarom, T., \& Lukitoaji, B. D. (2020). The level of self-regulated learning and self-awareness in science learning in the covid-19 pandemic era. Jurnal Pendidikan IPA Indonesia, 9(4), 512-520. https://journal.unnes.ac.id/nju/ index.php/jpii/article/view/25544.

Barnard-Brak, L., Paton, V. O., \& Lan, W. Y. (2010). Profiles in self-regulated learning in the online learning environment. International Review of Research in Open and Distributed Learning, 11(1), 61-80. https://doi.org/10.19173/irrodl.v11i1.769.

Bejtkovskỳ, J. (2016). The current generations: The Baby Boomers, $\mathrm{X}, \mathrm{Y}$, and $\mathrm{Z}$ in the context of human capital management of the 21st century in selected corporations in the Czech Republic. Littera Scripta, 9(2), 25-45. http://cejsh.icm.edu. pl/cejsh/element/bwmeta1.element. desklight-7c96aad7-baf2-4177-9774$12201 \mathrm{~d} 546357$. 
Bernacki, M. L., Aguilar, A. C., \& Byrnes, J. P. (2011). Self-regulated learning and technology-enhanced learning environments: An opportunity-propensity analysis. In G. Dettori \& D. Persico (Eds.). Fostering Self-regulated Learning through ICT. Hershey, Pennsylvania: IGI Global, 1-26. https://www.igi-global. com/chapter/fostering-self-regulatedlearning-through/47145.

Brockett, R. G., \& Hiemstra, R. (2018). Selfdirection in adult learning: Perspectives on theory, research, and practice. London: Routledge. https://books. google.co.id/books?hl=en\&lr=\&id=LF5DwAAQBAJ.

Brown, G. T. L., Peterson, E. R., \& Yao, E. S. (2016). Student conceptions of feedback: Impact on self-regulation, self-efficacy, and academic achievement. British Journal of Educational Psychology, 86(4), 606-629. https://doi.org/10.1111/ bjep. 12126 .

Butler, D. L. (2002). Individualizing instruction in self-regulated learning. Theory into Practice, 41(2), 81-92. https://doi. org/10.1207/s15430421tip4102 4

Cai, R., Wang, Q., Xu, J., \& Zhou, L. (2020). Effectiveness of students' self-regulated learning during the COVID-19 pandemic. Science Insights, 34(1), 175182. https://papers.ssrn.com/sol3/papers. cfm?abstract id=3622569.

Cazan, A.-M. (2014, 24-25 April). Self-regulated learning and academic achievement in the context of online learning environments. Paper presented at The $10^{\text {th }}$ International Scientific Conference Elearning and Software For Education, Bucharest, Romania.

Ceylan, V. K., \& Kesici, A. E. (2017). Effect of blended learning to academic achievement. Journal of Human Sciences, 14(1), 308 320. https://www.j-humansciences.com/ ojs/index.php/IJHS/article/view/4141.

Churchill, G. A., \& Iacobucci, D. (2005). Marketing research: Methodological foundations. Mason, OH: Thomson/
South-Western Cengage Learning. https:// www.amazon.com/Marketing-ResearchMethodological-Foundations-Qualtrics/ $\mathrm{dp} / 1439081018$ ? asin $=1439081018 \&$ revis ionId=\&format $=4 \&$ depth $=1$.

Cooper, D. R., \& Schindler, P. S. (2006). Business research methods ( $9^{\text {th }}$ ed). Boston, MA: McGraw-Hill Irwin. http://sutlib2.sut. ac.th/sut contents/H139963.pdf.

Courtney, M., \& Wilhoite-Mathews, S. (2015). From distance education to online learning: Practical approaches to information literacy instruction and collaborative learning in online environments. Journal of Library Administration, 55(4), 261277. https://doi.org/10.1080/01930826.20 15.1038924 .

Dent, A. L., \& Koenka, A. C. (2016). The relation between self-regulated learning and academic achievement across childhood and adolescence: A meta-analysis. Educational Psychology Review, 28(3), 425-474. https://doi.org/10.1007/s10648015-9320-8.

Efklides, A. (2011). Interactions of metacognition with motivation and affect in selfregulated learning: The MASRL model. Educational Psychologist, 46(1), 6-25. https://www.tandfonline.com/doi/abs/10. 1080/00461520.2011.538645.

Fan, Y., Chen, J., Shirkey, G., John, R., Wu, S. R., Park, H., \& Shao, C. (2016). Applications of structural equation modeling (SEM) in ecological studies: An updated review. Ecological Processes, 5(1), 1-12. https:// doi.org/10.1186/s13717-016-0063-3.

Fredricks, J. A., Blumenfeld, P. C., \& Paris, A. H. (2004). School engagement: Potential of the concept, state of the evidence. Review of Educational Research, 74(1), 59-109. https://doi. org/10.3102/00346543074001059.

Goudzwaard, M., Finkelstein, A., \& Petersen, R. (2017, 14 August). Learning OOS The Now Generation Digital Learning Environment. https://er.educause.edu/ articles/2017/8/1earningos-the-nowgeneration-digital-learning-environment. 
Hamid, S., Waycott, J., Kurnia, S., \& Chang, S. (2015). Understanding students' perceptions of the benefits of online social networking use for teaching and learning. The Internet and Higher Education, 26, 1-9. https://doi.org/10.1016/j. iheduc.2015.02.004.

Handoko, E., Gronseth, S. L., McNeil, S. G., Bonk, C. J., \& Robin, B. R. (2019). Goal setting and MOOC completion: A study on the role of self-regulated learning in student performance in massive open online courses. International Review of Research in Open and Distributed Learning, 20(3), 39-58. https://doi. org/10.19173/irrodl.v20i4.4270.

Harris, K. R., Graham, S., MacArthur, C. A., Reid, R., \& Mason, L. H. (2011). Selfregulated learning processes and children's writing. In B. J. Zimmerman \& D. H. Schunk (Eds.). Educational psychology handbook series. Handbook of selfregulation of learning and performance $\left(1^{\text {st }}\right.$ ed). New York, NY: Routledge/Taylor \& Francis Group, pp. 187-202. https:// doi.org/10.4324/9780203839010.

Hudaifah, F. (2020). The role of self-regulated learning in the covid-19 pandemic era. Biormatika: Jurnal Ilmiah Fakultas Keguruan dan Ilmu Pendidikan, 6(02), 76-84. http://ejournal.unsub.ac.id/index. php/FKIP/article/view/773.

Jena, P. C. (2013). Effect of smart classroom learning environment on academic achievement of rural high achievers and low achievers in science. International Letters of Social and Humanistic Sciences, 3, 1-9. https://doi.org/10.18052/www. scipress.com/ILSHS.3.1.

Johnson, G., \& Davies, S. (2014). Self-regulated learning in digital environments: Theory, research, praxis. British Journal of Research, 1(2), 1-14. https://www. imedpub.com/abstract/selfregulatedlearning-in-digital-environments-theoryresearch-praxis-9997.html.

Kakasevski, G., Mihajlov, M., Arsenovski, S., \& Chungurski, S. (2008, 23-26
June). Evaluating usability in learning management system moodle. Paper presented at ITI 2008 - 30th International Conference on Information Technology Interfaces, Cavtat, Croatia. https://doi. org/10.1109/ITI.2008.4588480.

Kaplan, A. M., \& Haenlein, M. (2016). Higher education and the digital revolution: About MOOCs, SPOCs, social media, and the Cookie Monster. Business Horizons, 59(4), 441-450. https://doi.org/10.1016/j. bushor.2016.03.008.

Kizilcec, R. F., Pérez-Sanagustín, M., \& Maldonado, J. J. (2017). Self-regulated learning strategies predict learner behavior and goal attainment in Massive Open Online Courses. Computers \& Education, 104, 18-33. https://doi.org/10.1016/j. compedu.2016.10.001.

Klein, P., Ivanjek, L., Dahlkemper, M. N., Jeličić, K., Geyer, M. A., Küchemann, S., \& Susac, A. (2021). Studying physics during the COVID-19 pandemic: Student assessments of learning achievement, perceived effectiveness of online recitations, and online laboratories. Physical Review Physics Education Research, 17(1), 1-11. https:// journals.aps.org/prper/abstract/10.1103/ PhysRevPhysEducRes.17.010117.

Kondo, M., Ishikawa, Y., Smith, C., Sakamoto, K., Shimomura, H., \& Wada, N. (2012). Mobile assisted language learning in university EFL courses in Japan: Developing attitudes and skills for selfregulated learning. ReCALL: The Journal of EUROCALL, 24(2), 169-187. https:// doi.org/10.1017/S0958344012000055.

Kosnin, A. M. (2007). Self-regulated learning and academic achievement in Malaysian undergraduates. International Education Journal, 8(1), 221-228. https:// openjournals.library.sydney.edu.au/index. php/IEJ/issue/view/546.

Kusumaningrum, D. E., Budiarti, E. M., Triwiyanto, T., \& Utari, R. (2020, 17 October). The effect of distance learning in an online learning framework on 
student learning independence during the Covid-19 pandemic. Paper presented at 2020 6th International Conference on Education and Technology (ICET), Malang, Indonesia. https://doi. org/10.1109/ICET51153.2020.9276564.

Laird, T. F. N., \& Kuh, G. D. (2005). Student experiences with information technology and their relationship to other aspects of student engagement. Research in Higher Education, 46(2), 211-233. https://doi. org/10.1007/s11162-004-1600-y.

Luo, Y. (2007). A coopetition perspective of global competition. Journal of World Business, 42(2), 129-144. https://doi. org/10.1016/j.jwb.2006.08.007.

Martin, F., Budhrani, K., \& Wang, C. (2019). Examining faculty perception of their readiness to teach online. Online Learning, 23(3), 97-119. http://dx.doi. org/10.24059/olj.v23i3.1555.

Nietfeld, J. L. (2017). The role of selfregulated learning in digital games. In P. A. Alexander, D. H. Schunk, \& J. A. Greene (Eds.). Handbook of SelfRegulation of Learning and Performance. Ney York, NY: Routledge, 271-284. https://www.taylorfrancis.com/chapters/ edit/10.4324/9781315697048-18/roleself-regulated-learning-digital-gamesjohn-nietfeld.

Oswald, F. L., Schmitt, N., Kim, B. H., Ramsay, L. J., \& Gillespie, M. A. (2004). Developing a biodata measure and situational judgment inventory as predictors of college student performance. Journal of Applied Psychology, 89(2), 187-207. https://doi.org/10.1037/00219010.89.2.187.

Panadero, E. (2017). A review of self-regulated learning: Six models and four directions for research. Frontiers in psychology, 8(422), 1-28. https://doi.org/doi:10.3389/ fpsyg.2017.00422.

Paris, S. G., \& Paris, A. H. (2001). Classroom applications of research on self-regulated learning. Educational Psychologist,
36(2), 89-101. https://doi.org/10.1207/ $\underline{\mathrm{S} 15326985 \mathrm{EP} 36024 .}$.

Peel, K. L. (2020). Everyday classroom teaching practices for self-regulated learning. Issues in Educational Research, 30(1), 260-282. http://www.iier.org.au/iier30/ peel-abs.html.

Pekrun, R., Goetz, T., Titz, W., \& Perry, R. P. (2002). Academic emotions in students' self-regulated learning and achievement A program of qualitative and quantitative research. Educational Psychologist, 37(2), 91-105. https://doi.org/10.1207/ S15326985EP3702 4.

Peters, O. (2000). Digital learning environments: New possibilities and opportunities. The International Review of Research in Open and Distributed Learning, 1(1), 1-19. https://doi.org/10.19173/irrodl.v1i1.3.

Putri, H. E., Muqodas, I., Sasqia, A. S., Abdulloh, A., \& Yuliyanto, A. (2020). Increasing self-regulated learning of elementary school students through the concretepictorial-abstract approach during the COVID-19 pandemic. Premiere Educandum: Jurnal Pendidikan Dasar dan Pembelajaran, 10(2), 187-202. http:// doi.org/10.25273/pe.v10i2.7534.

Reparaz, C., Aznárez-Sanado, M., \& Mendoza, G. (2020). Self-regulation of learning and MOOC retention. Computers in Human Behavior, 111, 106423. https://doi. org/10.1016/j.chb.2020.106423.

Rubulotta, F., Soliman-Aboumarie, H., Filbey, K., Geldner, G., Kuck, K., Ganau, M., \& Hemmerling, T. M. (2020). Technologies to optimize the care of severe coronavirus disease 2019 patients for health care providers challenged by limited resources. Anesthesia \& Analgesia, 131(2), 351-364. https://doi.org/10.1213/ ANE.0000000000004985.

Sahu, P. (2020). Closure of universities due to coronavirus disease 2019 (COVID-19): impact on education and mental health of students and academic staff. Cureus, 12(4), 1-6. https://doi.org/10.7759/cureus.7541. 
Salvo, S. G., Welch, B., \& Shelton, K. (2019). African American males learning online: Promoting academic achievement in higher education. Online Learning, 23(1), 22-36. http://dx.doi.org/10.24059/olj. v23i1.1390.

Schraw, G., Crippen, K. J., \& Hartley, K. (2006). Promoting self-regulation in science education: Metacognition as part of a broader perspective on learning. Research in Science Education, 36(1), 111-139. https://doi.org/10.1007/s11165-005-3917$\underline{8}$.

Schunk, D. H. (1995). Inherent details of self-regulated learning include student perceptions. Educational Psychologist, 30(4), 213-216. https://doi.org/10.1207/ s15326985ep3004 7.

Schunk, D. H., \& Zimmerman, B. J. (1998). Self-regulated learning: From teaching to self-reflective practice. London: Guilford Press.

Song, L., \& Hill, J. R. (2007). A conceptual model for understanding self-directed learning in online environments. Journal of Interactive Online Learning, 6(1), 27-42. http://www.ncolr.org/issues/ jiol/v6/n1/a-conceptual-model-forunderstanding-self-directed-learning-inonline-environments.html.

Uka, A., \& Uka, A. (2020). The effect of students' experience with the transition from primary to secondary school on self-regulated learning and motivation. Sustainability, 12(20), 1-16. https://doi.org/10.3390/su12208519.

Vovides, Y., Sanchez-Alonso, S., Mitropoulou, V., \& Nickmans, G. (2007). The use of e-learning Course Management Systems to support learning strategies and to improve self-regulated learning. Educational Research Review, 2(1), 64-74. https://doi. org/10.1016/j.edurev.2007.02.004.

Wang, C. -H., Shannon, D. M., \& Ross, M. E. (2013). Students' characteristics, selfregulated learning, technology selfefficacy, and course outcomes in online learning. Distance Education, 34(3), 302323. https://doi.org/10.1080/01587919.20 13.835779 .

Wei, H. -C., Peng, H., \& Chou, C. (2015). Can more interactivity improve learning achievement in an online course? Effects of college students' perception and actual use of a course-management system on their learning achievement. Computers \& Education, 83, 10-21. https://doi. org/10.1016/j.compedu.2014.12.013.

Wei, M., Zhou, Y., Barber, C., \& den Brok, P. (2015). Chinese students' perceptions of teacher-studentinterpersonal behaviorand implications. System, 55, 134-144. https:// doi.org/10.1016/j.system.2015.09.007.

Winne, P. H. (2005). Key issues in modeling and applying research on self-regulated learning. Applied Psychology: An International Review, 54(2), 232238. $\quad$ https://doi.org/10.1111/j.14640597.2005.00206.x.

Wolters, C. A., \& Hussain, M. (2015). Investigating grit and its relations with college students' self-regulated learning and academic achievement. Metacognition and Learning, 10(3), 293-311. https://doi. org/10.1007/s11409-014-9128-9.

Yamada, M., Yin, C., Shimada, A., Kojima, K., Okubo, F., \& Ogata, H. (2015, 6-9 July). Preliminary research on self-regulated learning and learning logs in a ubiquitous learning environment. Paper presented at 2015 IEEE 15th International Conference on Advanced Learning Technologies, Hualien, Taiwan. https://doi.org/10.1109/ ICALT.2015.74.

Yamagata-Lynch, L. C. (2014). Blending online asynchronous and synchronous learning. International Review of Research in Open and Distributed Learning, 15(2), 189-212. https://doi.org/10.19173/irrodl. v15i2.1778.

Yot-Domínguez, C., \& Marcelo, C. (2017). University students' self-regulated learning using digital technologies. International Journal of Educational 
Technology in Higher Education, 14(1), 1-18. https://doi.org/10.1186/s41239017-0076-8.

Zhang, D., Zhao, J. L., Zhou, L., \& Nunamaker Jr, J. F. (2004). Can e-learning replace classroom learning? Communications of the ACM, 47(5), 75-79. https://doi. org/10.1145/986213.986216.

Zimmerman, B. J. (1989). Models of selfregulated learning and academic achievement. In B. J. Zimmerman \& D. H. Schunk (Eds.), Self-regulated learning and academic achievement. New York, NY: Springer, pp. 1-25. https://hal.univbrest.fr/TICE/hal-00703019v1.

Zimmerman, B. J. (1990). Self-regulated learning and academic achievement: An overview. Educational Psychologist, 25(1), 3-17. https://doi.org/10.1207/ s15326985ep2501 2 .
Zimmerman, B. J. (2011). Motivational sources and outcomes of self-regulated learning and performance. In B. J. Zimmerman \& D. H. Schunk (Eds.). Handbook of selfregulation of learning and performance. New York, NY: Routledge, pp. 49-64. https://doi.org/10.4324/9780203839010.

Zimmerman, B. J., \& Schunk, D. H. (2012). Self-regulated learning and academic achievement: Theory, research, and practice. New York, NY: Routledge. https://doi.org/10.1007/978-1-46123618-4.

Zimmerman, B. J., Bonner, S., \& Kovach, R. (1996). Developing self-regulated learners: Beyond achievement to selfefficacy. Washington, DC: American Psychological Association. https://doi. org/10.1037/10213-000. 